\title{
Acid Glycohydrolase in Chinese Hamster with Spontaneous Diabetes
}

\author{
IV. Diabetes- and Line-dependent Variation in Plasma Enzyme Activity
}

\author{
A. Y. Chang and C. S. Perry \\ Diabetes and Atherosclerosis Research, The Upjohn Company, Kalamazoo, Michigan, USA
}

\begin{abstract}
Summary. The acitivity of five glycohydrolases was measured in the plasma of Chinese hamsters from eight highly inbred lines in the Upjohn colony. The diabetic animals showed elevated activities of plasma $\beta$-D-galactosidase, $\quad \mathrm{N}$-acetyl- $\beta$-D-glucosaminidase and $\mathrm{N}$-acetyl- $\beta$-D-galactosaminidase but similar activities of plasma $\alpha$-D-glucosidase and $\alpha$-D-galactosidase to the nondiabetic animals. Line-specific variation was observed in all five enzymes and anomalies were especially evident in N-acetyl- $\beta$-Dglucosaminidase and $\mathrm{N}$-acetyl- $\beta$-D-galactosaminidase activity. In two diabetic lines, $\mathrm{AC}$ and $\mathrm{Z}$, activities of these two enzymes were not elevated although significant correlation was found with blood sugar levels. The pronounced difference in the plasma activity of $\mathrm{N}$-acetyl- $\beta$-D-glucosaminidase in two diabetic lines, $\mathrm{XA}$ and $\mathrm{AC}$, did not involve plasma inhibitors or activators, as evidenced by the coincidence in observed and calculated activities in mixed plasma samples, or specific isozymes, concluded from the similar elution profiles on ionexchange column and thermostability curves. These data suggest that diabetes-related changes in plasma glycohydrolase activities are dictated by genetic factors and may be involved in the development of complications.
\end{abstract}

Key words: Plasma glycohydrolases, $\alpha$-D-galactosidase, $\beta$-D-galactosidase, $\mathrm{N}$-acetyl- $\beta$ - $\mathrm{D}$-glucosaminidase, $\mathrm{N}$-acetyl- $\beta$-D-galactosaminidase, $\alpha$-D-glucosidase, Chinese hamster, hyperglycaemia, diabetes.

Elevation in the activities of a number of plasma or serum glycohydrolases has been reported in human diabetic patients [1-4] and in chemically induced diabetic rats and Chinese hamsters [5-7]. In view of their functional activities in the degradation of glycoproteins and glycosaminoglycans which have been implicated in the development of diabetic complications $[8,9]$, the changes in glycohydrolase activities may play important roles in the pathophysiology of the diabetic sequelae. However, the relationship between hyperglycaemia and alterations in these plasma enzymes was seriously questioned by the observation that the streptozotocin-induced and genetically diabetic $(d b / d b)$ mice showed lower, instead of higher, activity of plasma glycohydrolases than the nondiabetic control mice [6]. These contradictory findings could arise from species-related difference and heterogeneity in the etiology of the various types of diabetes studied. Previously, we have demonstrated that the hereditary diabetic Chinese hamsters of the XA line in the Upjohn colony showed twice as much plasma $\mathrm{N}$-acetyl- $\beta$-D-glucosaminidase (EC 3.2.1.30) activity as the nondiabetic $M$ line and there was a significant correlation between blood sugar and its activity $[10,11]$. However, these Chinese hamsters were highly inbred; line-dependent variation unrelated to the manifestation of hyperglycaemia has been found in tissue lactate dehydrogenase (LDH) (EC 1.1.1.27) isozyme pattern and the development of diabetes further affected LDH isozyme distribution [12]. Moreover, although significant correlations between the diabetic syndrome in the Chinese hamsters and such biochemical and endocrine entities as renal glycohydrolase activities and plasma pancreatic insulin and glucagon contents were repeatedly observed, these parameters also showed line-specific variation in their response or relationship to the manifestation of diabetes $[13,14]$. Therefore, a study on plasma glycohydrolase activities in the Upjohn colony of Chinese hamsters with spontaneous diabetes may shed new light on the effect of this disorder on 
Table 1. Blood sugar, age, duration of glycosuria, body weight, and plasma glycohydrolase in diabetic and nondiabetic Chinese hamsters ${ }^{\mathrm{a}}$

\begin{tabular}{|c|c|c|c|c|c|c|}
\hline \multirow{2}{*}{$\begin{array}{l}\text { Measurements } \\
\text { Age }\end{array}$} & \multirow{2}{*}{$\begin{array}{l}\text { Unit } \\
\text { months }\end{array}$} & \multicolumn{2}{|c|}{ Nondiabetic } & \multicolumn{2}{|l|}{ Diabetic } & \multirow{2}{*}{$\frac{\mathrm{P}^{\mathrm{b}}}{<0.025}$} \\
\hline & & 18.6 & $\pm 0.5(14)$ & 16.3 & $\pm 0.5(34)$ & \\
\hline Duration of glycosuria & months & - & & 14.3 & $\pm 0.5(34)$ & - \\
\hline Body weight & $\mathrm{g}$ & 34.2 & $\pm 0.5(14)$ & 33.8 & $\pm 0.6(34)$ & NS \\
\hline Blood sugar & $\mathrm{mg} / 100 \mathrm{ml}$ & 65 & $\pm 3(14)$ & 309 & $\pm 13(34)$ & $<0.001$ \\
\hline$\alpha$-D-galactosidase & $\mathrm{nmol} / \mathrm{min} / \mathrm{ml}$ & 0.97 & \pm 0.04 & 1.09 & $\pm 0.05(34)$ & NS \\
\hline$\beta$-D-galactosidase &, & 0.356 & \pm 0.037 & 0.567 & $\pm 0.023(34)$ & $<0.001$ \\
\hline $\mathrm{N}$-acetyl- $\beta$-D-glucosaminidase & $"$ & 26.8 & $\pm 1.4(14)$ & 43.4 & $\pm 4.4(34)$ & $<0.025$ \\
\hline $\mathrm{N}$-acetyl- $\beta$-D-galactosaminidase & 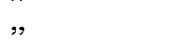 & 3.58 & $\pm 0.47(14)$ & 7.80 & $\pm 0.83(28)$ & $<0.001$ \\
\hline$\alpha$-D-glucosidase & $"$ & 40.7 & $\pm 3.5(14)$ & 39.9 & $\pm 1.6(34)$ & NS \\
\hline
\end{tabular}

a Mean \pm SEM (Number of observations)

b NS denotes not significant

plasma glycohydrolases as well. The present study was carried out for this purpose.

\section{Material and Methods}

The diabetic Chinese hamsters were selected from six highly inbred lines (AC, AH, L, OT, XA and $\mathrm{Z}$ ) and the nondiabetic from two ( $A V$ and $M$ ). These lines were propagated by matings between siblings using glycosuria or aglycosuria as phenotypic endpoints for selection [13]. The numbers of inbreeding generations for the animals used in the present study are as follows: $\mathrm{AC}$ (14th-16th), XA (17th-18th), AH (14th-15th), Z (15th), OT (8th-9th), L (30th-31th), AV (7th-8th), and M (16th). All animals were male, 15-19 months old, allowed food and water ad libitum and housed in individual cages.

The animals were bled through the orbital sinus in the morning and $0.4-0.8 \mathrm{ml}$ of blood was collected and mixed with 2 drops of heparin. A $20 \mu \mathrm{l}$ portion was quickly diluted with $1 \mathrm{ml} 0.6 \mathrm{~mol} / \mathrm{l}$ $\mathrm{NaF}$ and kept frozen at $-70^{\circ} \mathrm{C}$ for blood sugar determination $2-4$ weeks later [15]. Plasma was collected from the remaining portion of blood by centrifugation and assayed for various glycohydrolases on the same day.

4-Methylumbelliferyl glycosides $(0.25 \mathrm{mmol} / 1)$ were dissolved in buffers containing $0.1 \mathrm{~mol} / 1 \mathrm{Na}_{2} \mathrm{HPO}_{4}$ and $0.05 \mathrm{~mol} / 1 \mathrm{citric}$ acid at appropriate $\mathrm{pH}$. These solutions served as substrates. Enzyme activity was measured fluorometrically [16] after incubating $0.2 \mathrm{ml}$ substrates with $0.01 \mathrm{ml}$ diluted plasma samples at $37^{\circ} \mathrm{C}$ for 30 minutes; zero time controls served as blanks. Plasma was diluted one hundred fold for $\alpha$-D-glucosidase (EC 3.2.1.20) and $\mathrm{N}$-acetyl$\beta$-D-glucosaminidase, one twentieth for $\mathrm{N}$-acetyl- $\beta$-D-galactosaminidase (EC 3.2.1.30) and two fold for $\alpha$-D-galactosidase (EC 3.2.1.22) and $\beta$-D-galactosidase (EC 3.2.1.23) with chilled distilled water. At these dilutions, each enzyme showed linearity at 30 minutes of incubation. 4-Methylumbelliferone $(0-0.4 \mathrm{nmol})$ served as standards in each individual assay. Enzymes were assayed at their optimal pH, i. e. 6.5 for $\alpha$-D-glucosidase and 4.5 for the other four enzymes.

In the study on thermostability of $\mathrm{N}$-acetyl- $\beta$-D-glucosaminidase, plasma was diluted 1 to 50 with distilled water and $0.2 \mathrm{ml}$ portions in glass tubes sealed with parafilm were incubated in a water bath at various temperature for 15 minutes. The heating was terminated by immersing the tubes in a water-ice mixture and $0.2 \mathrm{ml}$ chilled distilled water was added into the heated samples just before enzyme assay.

Plasma samples $(0.2 \mathrm{ml})$ from $\mathrm{AC}$ and XA line animals were chromatographed at $5^{\circ} \mathrm{C}$ on DEAE-Sepharose $\mathrm{CL}-6 \mathrm{~B}$ column
$(0.9 \times 15 \mathrm{~cm})$ equilibrated in $0.01 \mathrm{~mol} / 1 \mathrm{NaH}_{2} \mathrm{PO}_{4} \cdot \mathrm{Na}_{2} \mathrm{HPO}_{4}, \mathrm{pH}$ $6.0,1 \mathrm{~g} / 1 \mathrm{NaN}_{3}$ and eluted with a linear gradient made by mixing $50 \mathrm{ml}$ each of 0 to $0.25 \mathrm{~mol} / 1 \mathrm{NaCl}$ in the same buffer. Fractions of $1.1-1.2 \mathrm{ml}$ were collected. For $\alpha$-D-galactosidase and $\beta$-D-galactosidase assays, $0.1 \mathrm{ml}$ aliquots of each even-numbered tube were incubated with $0.2 \mathrm{ml} 0.25 \mathrm{mmol} / 1$ 4-methylumbelliferyl glycosides at $37^{\circ} \mathrm{C}$ for 60 minutes. For $\alpha$-D-glucosidase and $\mathrm{N}$-acetyl$\beta$-D-glucosaminidase assays, $0.01 \mathrm{ml}$ aliquots were used and for $\mathrm{N}$-acetyl- $\beta$-D-galactosaminidase, $0.05 \mathrm{ml}$ aliquots.

Statistical analyses were carried out according to Student's $t$ test and NS indicates $\mathrm{p}>0.05$.

\section{Results}

\section{Comparison between Diabetic and Nondiabetic Chinese Hamsters}

Comparison of the diabetic and nondiabetic animals is summarized in Table 1.

The mean age of the 34 diabetic Chinese hamsters used in the present study was slightly lower than that of the 14 nondiabetic animals and they had been glycosuric for about 14 months. The glycosuric animals were also hyperglycaemic (309 $\pm 13 \mathrm{mg}$ / $100 \mathrm{ml}$ ) but they showed similar body weights as the aglycosuric animals despite the fact that they were slightly younger on the average. Among the five plasma glycohydrolases measured, $\alpha$-D-galactosidase and $\alpha$-D-glucosidase showed similar activities between diabetic and nondiabetic animals, whereas significantly higher activities of $\beta$-D-galactosidase, $\mathrm{N}$-acetyl- $\beta$-D-glucosaminidase and $\mathrm{N}$-acetyl- $\beta$-Dgalactosaminidase were observed in the diabetic animals. $\beta$-D-glucosidase was also measured at $\mathrm{pH} 5.5$ and negligible activity was found in plasma.

Line-Specific Difference in Blood Sugar Level, Duration of Glycosuria and Body Weight. The duration of glycosuria varied between the lines and was related to the age of the animals (Table 2). Despite the lack 


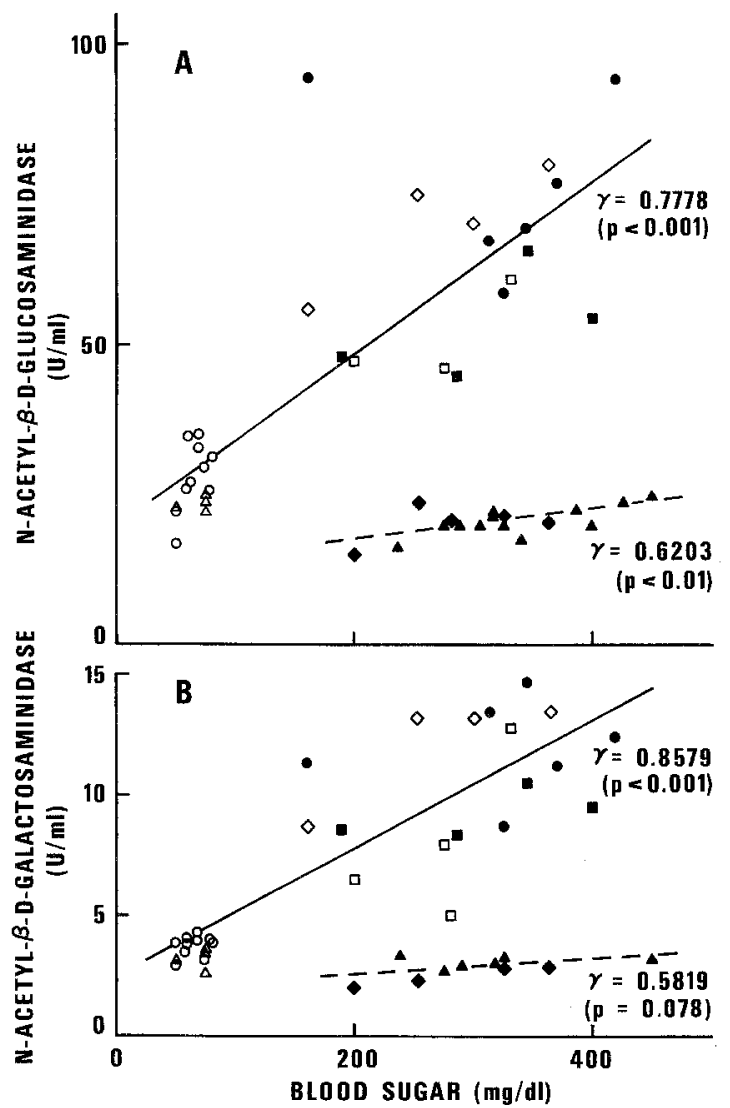

Fig. 1. Correlations between blood sugar level and the activities of plasma $\mathrm{N}$-acetyl $\beta$-D-glucosaminidase (A) and $\mathrm{N}$-acetyl- $\beta$-Dgalactosaminidase $(\mathbf{B})$. THe following symbols represent animals from specific lines: $\mathrm{AC}(\boldsymbol{\Delta}), \mathrm{Z}(\bullet), \mathrm{XA}(\bullet), \mathrm{AH}(\boldsymbol{\varpi}), \mathrm{L}(\square)$, OT $(\square), M(O)$, and $\operatorname{AV}(\triangle)$.

of uniformity in the age of these animals, line-specific variation in body weight was evident. Thus, The $\mathrm{AH}$ line animals tended to be overweight since they were the heaviest, yet they were also among the youngest. The $\mathrm{Z}$ line Chinese hamsters weighed the least, although they were also the oldest. Therefore, difference in body weights constituted one of the heterogeneous factors in the diabetic population in the Upjohn Chinese hamster colony.

Line-Specific Difference in Plasma Glycohydrolase Activities. Although the diabetic animals in lines XA, $\mathrm{Z}$, and $\mathrm{L}$ showed significantly higher plasma $\alpha-\mathrm{D}$ galactosidase than those in nondaibetic $\mathrm{AV}$ and $\mathrm{M}$ lines, the animals in the other three diabetic lines, $\mathrm{AC}, \mathrm{AH}$, and $\mathrm{OT}$, showed similar activities of plasma $\alpha$-D-galactosidase as those in $\mathrm{AV}$ and $\mathrm{M}$; there was also no significant difference in plasma $\alpha$-D-galactosidase activity between the two nondiabetic lines (Table 2).

In contrast, the plasma activities of $\beta$-D-galactosidase were higher in all diabetic lines. The line-

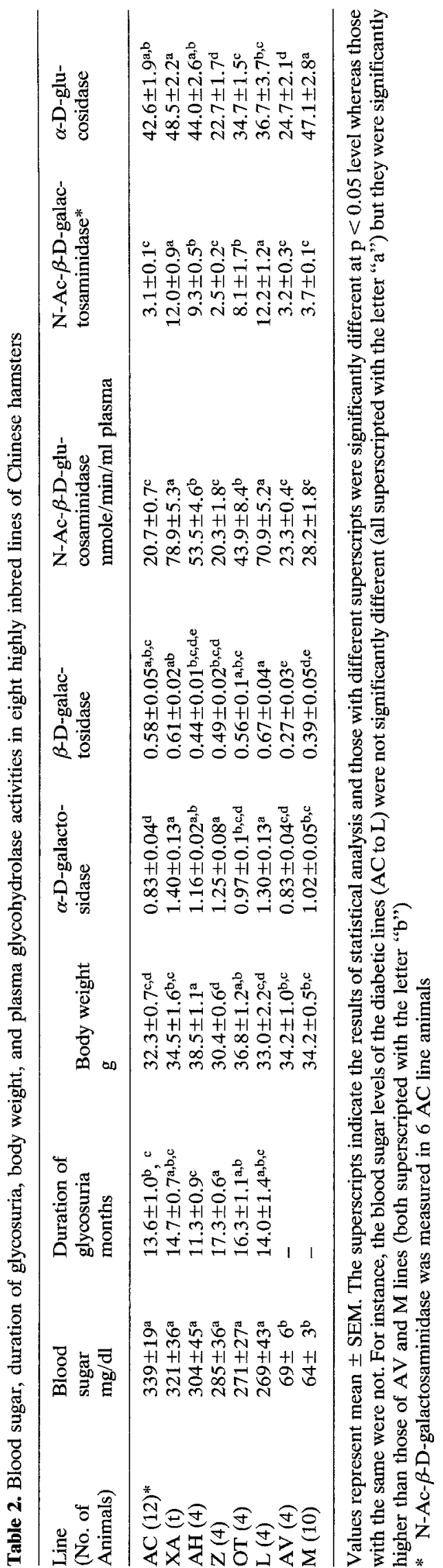


Table 3. Correlation coefficients between blood sugar level and plasma glycohydrolases and between different glycohydrolases

\begin{tabular}{|c|c|c|c|c|c|}
\hline & $\begin{array}{l}\alpha \text {-D galac- } \\
\text { tosidase }\end{array}$ & $\begin{array}{l}\beta \text {-D-galac- } \\
\text { tosidase }\end{array}$ & $\begin{array}{l}\text { N-Ac- } \beta \text {-D- } \\
\text { glucosaminidase }\end{array}$ & $\begin{array}{l}\mathrm{N}-\mathrm{Ac}-\beta \text {-D- } \\
\text { galactosaminidase }\end{array}$ & $\begin{array}{l}\alpha \text {-D-gluco- } \\
\text { sidase }\end{array}$ \\
\hline \multirow[t]{2}{*}{ Blood sugar } & 0.096 & 0.536 & 0.267 & 0.488 & 0.082 \\
\hline & NS & $\mathrm{P}<0.001$ & NS & $P=0.001$ & NS \\
\hline \multirow[t]{2}{*}{$\alpha$-D-galactosidase } & - & 0.177 & 0.707 & 0.607 & 0.115 \\
\hline & & NS & $\mathbf{P}<0.001$ & $P<0.001$ & NS \\
\hline \multirow[t]{2}{*}{$\beta$-D-galactosidase } & - & - & 0.314 & 0.475 & 0.174 \\
\hline & & & $P=0.03$ & $\mathrm{P}=0.001$ & NS \\
\hline \multirow{2}{*}{$\begin{array}{l}\mathrm{N}-\mathrm{Ac}-\beta-\mathrm{D} \text {-gluco- } \\
\text { saminidase }\end{array}$} & - & - & - & 0.932 & 0.266 \\
\hline & & & & $\mathrm{P}<0.001$ & NS \\
\hline $\begin{array}{l}\mathrm{N}-\mathrm{Ac}-\beta \text {-D-galac- } \\
\text { tosaminidase }\end{array}$ & - & - & - & - & $\begin{array}{l}0.272 \\
\text { NS }\end{array}$ \\
\hline
\end{tabular}

Total numbers of observations were 48 for each variable except $\mathrm{N}$-Ac- $\beta$-D-galactosaminidase which had 42 . Because of the even distribution of all these values, linear correlation coefficients were calculated. NS denotes not significant at $\mathrm{p}<0.05$ level

Table 4. Effect of mixing AC and XA plasma samples on N-acetyl$\beta$-D-glucosaminidase activity

\begin{tabular}{lll}
\hline Sample & Found & Calculated \\
\hline & nmol/min/ml & \\
XA-line & 98.7 & - \\
XA $=$ AC $(3=1)$ & 88.8 & 80.4 \\
XA $=$ AC $(1=1)$ & 62.7 & 62.0 \\
XA = AC $(1=3)$ & 40.2 & 43.7 \\
AC-line & 25.4 & - \\
\hline
\end{tabular}

All values are averages of duplicate runs

related variations in plasma $\mathrm{N}$-acetyl- $\beta$-Dglucosaminidase and $\mathrm{N}$-acetyl- $\beta$-D-galactosaminidase were more complex, however. Both enzymes showed three separate levels of activity in the eight lines of animals studied. Lines XA and $\mathrm{L}$ had the highest activity, AH and OT the medium, and AC, Z, $\mathrm{AV}$, and $\mathrm{M}$ the lowest (Table 2). Highly significant correlation $(p<0.001)$ between blood sugar levels and enzyme activities were observed (Fig. 1) with lines $\mathrm{AC}$ and $\mathrm{Z}$ sharing a separate relationship to the other 6 lines.

Plasma $\alpha$-D-glucosidase activity showed no apparent relationship to the condition of diabetes (Tables 1 and 2). Diabetic line $Z$ and non-diabetic line AV had the lowest plasma $\alpha$-D-glucosidase activity whereas diabetic line XA and nondiabetic line $\mathrm{M}$ showed the highest.

Correlations between Blood Sugar Level and Plasma Glycohydrolases and between Different Glycohydrolases. A highly significant correlation $(\mathrm{p}<0.001)$ was found between blood sugar level and plasma $\beta$-Dgalactosidase activity, whereas no correlation was evident between blood sugar level and the activities of plasma $\alpha$-D-galactosidase and $\alpha$-D-glucosidase (Table 3). These results were in accord with the data in Table 1 when the diabetic and nondiabetic animals were treated as distinct groups. When data from all the animals were grouped together, correlations with blood sugar levels were also observed for plasma $\mathrm{N}$ acetyl- $\beta$-D-glucosaminidase $(\mathrm{p}=0.067)$ and $\mathrm{N}$ acetyl- $\beta$-D-galactosaminidase $(\mathrm{p}<0.001)$ (Table 3$)$. The higher level of significance found in $\mathrm{N}$-acetyl $-\beta$ $D$-galactosaminidase apparently stemmed from the fact that plasma from only six AC animals, which had anomalous levels, was analysed whereas twelve AC animals were studied for $\mathrm{N}$-acetyl- $\beta$-D-glucosaminidase.

Significant correlations between $\mathrm{N}$-acetyl- $\beta$-Dglucosaminidase and $\alpha$-D-galactosidase $(\mathrm{p}<0.001)$ and $\beta$-D-galactosidase $(\mathrm{p}=0.03)$; and between $\mathrm{N}$ acetyl- $\beta$-D-galactosaminidase and $\alpha$-D-galactosidase $(\mathrm{p}<0.001)$ and $\beta$-D-galactosidase $(\mathrm{p}=0.01)$; were also observed (Table 3 ). Parallelism with highly significant correlation, i. e., $r=0.9322$ and $\mathrm{p}<0.001$, between the activities of $\mathrm{N}$-acetyl- $\beta$-D-glucosaminidase and $\mathrm{N}$-acetyl- $\beta$-D-galactosaminidase was also found. Correlation between $\alpha$-D-glucosidase and the other glycohydrolases was lacking, however (Table $3)$.

Activities of $N$-Acetyl- $\beta$-D-Glucosaminidase in Mixed Plasma Samples of $A C$ and XA Line Animals. Table 4 shows the effect of mixing $X A$ and $\mathrm{AC}$ plasma samples on $\mathrm{N}$-acetyl- $\beta$ - $\mathrm{D}$-glucosaminidase activity. It is apparent that the difference in XA and AC line plasma $\mathrm{N}$-acetyl- $\beta$-D -glucosaminidase levels was not due to the presence of inhibitors or activators in the plasma samples since the activities in mixed samples at different ratios appeared to be additive.

Thermostability of Plasma $N$-Acetyl- $\beta-D$ Glucosaminidase of $A C$ and $X A$ Line Animals. Nacetyl- $\beta$-D-glucosaminidase exists in isozymic forms 


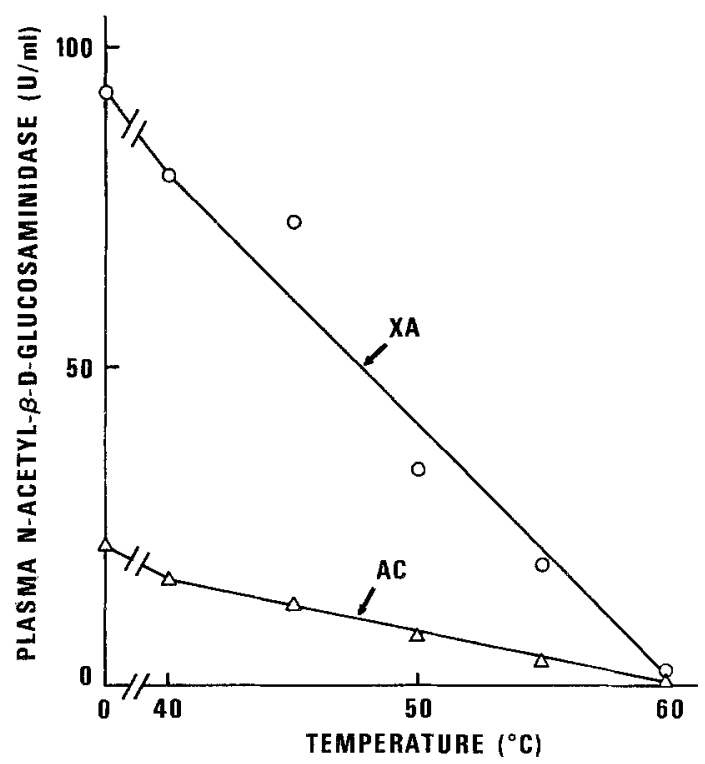

Fig. 2. Heat sensitivity of plasma $\mathrm{N}$-acetyl- $\beta$-D-glucosaminidase of $\mathrm{XA}$ and $\mathrm{AC}$ line animals. Arrows indicate the temperature at which $50 \%$ enzyme activity was lost after incubation for 15 minutes. Each point represents the average of two determinations

with different thermosensitivities [10]. Both $\mathrm{AC}$ and $\mathrm{XA}$ line plasma samples lost all of $\mathrm{N}$-acetyl- $\beta$-Dglucosaminidase activity after heating at $60^{\circ} \mathrm{C}$ for 15 minutes and both samples would have lost $50 \%$ of the total activity after heating at $47.5^{\circ} \mathrm{C}$ for 15 minutes (shown by arrows in Fig. 2). It, therefore, appears that $\mathrm{AC}$ and $\mathrm{XA}$ line animals contained similar proportion of plasma $\mathrm{N}$-acetyl- $\beta$-D-glucosaminidase isozymes.

Elution Profiles of Plasma Glycohydrolases of $A C$ and $X A$ Line Animals on DEAE-Sepharose CL- $6 B$ Columns. Ion-exchange column chromatography of plasma glycohydrolases of $\mathrm{AC}$ and XA animals was run for the purpose of identifying specific isozymes and co-activity between these glycohydrolases; the elution profiles are shown in Figure 3A (XA line) and 3B (AC line). Plasma $\alpha$-D-glucosidase, $\alpha-\mathrm{D}$ galactosidase and $\beta$-D-galactosidase were eluted off the columns as single peaks at $0.195,0.215$, and $0.120 \mathrm{~mol} / 1 \mathrm{NaCl}$ respectively for both $\mathrm{AC}$ and XA line animals. $\mathrm{N}$-acetyl- $\beta$-D-glucosaminidase and $\mathrm{N}$ acetyl- $\beta$-D-galactosaminidase emerged as two major and one minor peaks at $0.01,0.06$, and $0.12-0.15 \mathrm{~mol} / \mathrm{l} \mathrm{NaCl}$ in both Figures $3 \mathrm{~A}$ and $3 \mathrm{~B}$.

\section{Discussion}

The present study indicates that although some glycohydrolases are highly elevated in the plasma of

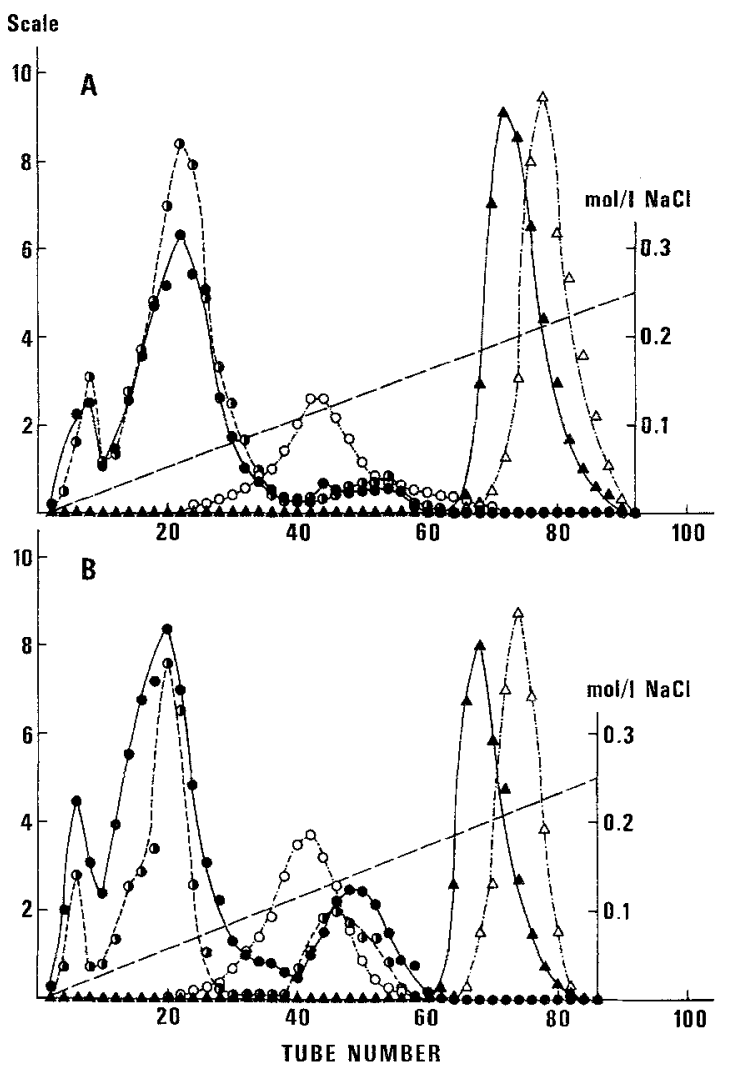

Fig. 3. DEAE-Sepharose CL-6B column chromatography of plasma glycohydrolases of $\mathrm{XA}$ and $\mathrm{AC}$ line animals. The graph shows one exemplary run of each line. A Pooled XA line sample. A scale of 10 represents the following units for each enzyme: $25 \mathrm{pmol} / \mathrm{min} / \mathrm{ml}$ for $\alpha$-D-galactosidase $(\triangle-\cdot-\triangle)$ and $\beta$-D-galactosidase $(\bigcirc \ldots O), 1 \mathrm{nmol} / \mathrm{min} / \mathrm{ml}$ for $\mathrm{N}$-acetyl- $\beta$-D glucosaminidase $(\mathbf{O}-\mathrm{D})$ and $\alpha$-D-glucosidase $(\mathbf{A}-\mathbf{\Lambda})$ and 0.2 $\mathrm{nmol} / \mathrm{min} / \mathrm{ml}$ for $\mathrm{N}$-acetyl- $\beta$-D-galactosaminidase (-). B Pooled AC line sample. Symbols for each enzyme are the same as in (A). A scale of 10 represents $10 \mathrm{pmol} / \mathrm{min} / \mathrm{ml}$ for $\alpha$-D-galactosidase and $\beta$-D-galactosidase, $100 \mathrm{pmol} / \mathrm{min} / \mathrm{ml}$ for $\mathrm{N}$-acetyl $\beta-$ $\mathrm{D}$-glucosaminidase, $20 \mathrm{pmol} / \mathrm{min} / \mathrm{ml}$ for $\mathrm{N}$-acetyl $\beta$-D-galactosaminidase and $1 \mathrm{nmol} / \mathrm{min} / \mathrm{ml}$ for $\alpha$-D-glucosidase

diabetic animals in certain highly inbred lines, the aberrant phenomena are quasi-general, in accordance with the inconsistency observed in diabetic humans and various animal models by several groups of investigators [1-7].

Among the five glycohydrolases reported in this study, only the activity of $\beta$-D-galactosidase was consistently higher in the plasma of the diabetic Chinese hamsters and it was significantly correlated to the severity of hyperglycaemia. Therefore, hyperglycaemia may play a causative role in or share a common antecedent with the elevation of plasma $\beta-D$ galactosidase in these diabetic animals. Contrariwise, although the activities of $\beta$-D-galactosidase and $\alpha$-Dglucosidase in the plasma also showed line-specific variations, they did not vary with the state of diabetes 
since no correlation to blood sugar level was found. It is thus concluded that the line-dependent difference in plasma $\alpha$-D-galactosidase and $\alpha$-D-glucosidase in the Chinese hamsters arose from genetic traits unrelated to diabetes.

Our data also suggest correlation between the state of diabetes and plasma $\mathrm{N}$-acetyl- $\beta$-Dglucosaminidase and $\mathrm{N}$-acetyl- $\beta$-D-galactosaminidase activities. The response of these two plasma enzymes to the manifestation of hyperglycaemia differed between the highly inbred lines and could be separated into two groups. Lines $\mathrm{XA}, \mathrm{L}, \mathrm{AH}$, and OT contained highly responsive animals whereas animals in $\mathrm{AC}$ and $\mathrm{Z}$ lines showed exceedingly modest response as they developed hyperglycaemia. The crucial question now remains as to what factor(s) caused the increase of these plasma enzymes in XA, L, AH, and OT line animals and/or what element(s) prevented $A C$ and $Z$ line animals to raise their plasma activities of these two enzymes during or after the onset of hyperglycaemia.

Elevation of plasma or serum $\mathrm{N}$-acetyl- $\beta-\mathrm{D}$ glucosaminidase has been found in human diabetic patients [1-4] and in the chemically induced diabetic rat $[5,6]$ and Chinese hamster [7]. A lack of response to hyperglycaemia regarding the plasma activity of $\mathrm{N}$-acetyl- $\beta$-D-glucosaminidase has also been reported in $d b / d b$ mouse at the early and hyperinsulinaemic stage and the streptozotocin-diabetic mouse [6], akin to our data in the $\mathrm{AC}$ and $\mathrm{Z}$ line Chinese hamsters. However, these diabetic mice also showed low plasma $\beta$-D-galactosidase activity, in contrast to what was observed in the $\mathrm{AC}$ and $\mathrm{Z}$ line Chinese hamsters. Therefore, the effect of diabetes on the elevation of plasma glycohydrolases appears to be extremely complex and may involve multiple and specific factors.

Plasma $\alpha$-D-galactosidase, $\beta$-D-galactosidase, and $\alpha$-D-glucosidase yielded distinct peaks of activity on DEAE-Sepharose CL-6B columns, indicating that these activities were elicited by specific enzymes. Two lines of experimental evidence suggest that $\mathrm{N}$ acetyl- $\beta$-D-glucosaminidase and $\mathrm{N}$-acetyl- $\beta$-Dgalactosaminidase activities were carried out by the same proteins: coincidental peaks on anion-exchange column and highly significant correlation in their activities in individual samples. Our data also suggest that the line-dependent variations in these enzymes were not caused by specific isozymes in view of the similarity in the elution profiles on anion-exchange column and the heat denatuation curves between XA and AC line samples. The coincidence in the measured and calculated activities in mixed plasma samples of XA and AC lines excluded the likelihood that inhibitory or activating factors were involved in caus- ing the line-dependent difference in $\mathrm{N}$-acetyl- $\beta$-Dglucosaminidase activity.

The ever-increasing list of biochemical and endocrine entities which show line-specific variation in the Upjohn colony of Chinese hamster [12-14] now includes the plasma glycohydrolases. The heterogeneity in these elements, either related or unrelated to the manifestation of hyperglycaemia, further attests to the genetic mosaicism in the diabetic population in the colony. The specificity held in these parameters may offer a unique opportunity to study their potential relationship to various pathological conditions associated with diabetes. The AC and $\mathrm{Z}$ line animals are of particular interest since they show low levels of plasma glycohydrolases which are implicated in diabetic microangiopathy [1-6]. Whether animals in $\mathrm{AC}$ and $\mathrm{Z}$ lines possess different proclivity to develop diabetic complications than others is now under investigation.

Acknowledgement. The authors thank the supply of animals by Dr. G. C. Gerritsen and Messrs. R. L. Miller and N. J. Smit.

\section{References}

1. Belfiore, F., LoVecchio, L., Napoli, E., Borzi, V.: Increased $\beta$ $\mathrm{N}$-acetyl-glucosaminidase activity in diabetes mellitus. Clin. Chem. 20, 1229-1230 (1974)

2. Belfiore, F., Napoli, E., LoVecchio, L.: Serum N-acetyl- $\beta-$ glucosaminidase activity in diabetic patients. Diabetes 21, 1167-1172 (1972)

3. Bomback, F. M., Nakagawa, S., Kumin, S., Nitowsky, H. M.: Altered lysosomal glycohydrolase activities in juvenile diabetes mellitus. Diabetes 25, 420-427 (1976)

4. Fushimi, H., Tarui, S.: Retina, tear, and serum $\beta$-N-acetylglucosaminidase activities in diabetic patients. Clin. Chim. Acta 71, 1-8 (1976)

5. Fushimi, H., Tarui, S.: Kidney and serum $\beta$-N-acetylglucosaminidase activities in streptozotocin diabetic rats and their responses to insulin and glucagon. J. Biochem. (Tokyo) 76, 225-227 (1974)

6. Tulsiani, D. R. P., Buschiazzo, H. O., Tolbert, B., Touster, O.: Changes in plasma hydrolase activities in hereditary and streptozotocin-induced diabetes. Arch. Biochem. Biophys. 181, 216-227 (1977)

7. Chang, A. Y., Noble, R. E., Wyse, B. M.: Streptozotocininduced diabetes in the Chinese hamster. Diabetologia 13, 595-602 (1977)

8. Spiro, R. G.: Investigations into the biochemical basis of diabetic basement-membrane alterations. Diabetes $\mathbf{2 5}$ [Suppl. 2], 909-913 (1976)

9. Kofoed, J. A., Bozzini, C. E., Alippi, R. M.: Skin acid glycosaminoglycans in alloxan diabetic rats. Diabetes 19 , 732-733 (1970)

10. Chang, A. Y.: Acid glycohydrolase in Chinese hamster with spontaneous diabetes. II. N-Acetyl- $\beta$-D-hexosaminidase in plasma and tissues. Biochim. Biophys. Acta 522, 503-514 (1978)

11. Chang, A. Y., Noble, R. E., Wyse, B. M.: Comparison of highly inbred diabetic and nondiabetic lines in the Upjohn colony of Chinese hamsters. Diabetes 26, 1063-1071 (1977) 
12. Chang, A. Y., Noble, R.E., Greenberg, H.S.: Variance in $\mathrm{LDH}$ isozyme patterns in a Chinese hamster (Cricetulus griseus) colony. Comp. Biochem. Physiol. [B] 58, 119-123 (1977)

13. Chang, A. Y., Greenberg, H. S.: Acid glycohydrolase in Chinese hamster with spontaneous diabetes. III. Line-dependent variance. Biochim. Biophys. Acta 525, 134-141 (1978)

14. Wyse, B. M., Chang, A. Y., Greenberg, H. S.: Glucose, insulin and glucagon levels in nondiabetic and spontaneously diabetic Chinese hamsters. Diabetes 27 [Suppl. 2],514 (1978)

15. Gerritsen, G. C., Dulin, W. E.: Effect of a new hypoglycemic agent, 3,5-dimethylpyrazole, on carbohydrate and free fatty acid metabolism. Diabetes 14, 507-515 (1965)
16. Robinson, D., Price, R. G., Dance, N.: Separation and properties of $\beta$-galactosidase, $\beta$-glucosidase, $\beta$-glucoronidase and $\mathrm{N}$ acetyl-glucosaminidase from rat kidney. Biochem. J. 102, 525-532 (1967)

Received: April 10, 1978

and in revised form: July 17, 1978

Dr. A. Y. Chang

Diabetes and Atherosclerosis Research

The Upjohn Company

Kalamazoo, MI 49001

USA 